\title{
The African Scholar as an 'Alienated Self'
}

\author{
Olusola Ayo-Obiremi* \\ Lecturer, The Nigerian Baptist Theological Seminary, Ogbomoso, Oyo State, Nigeria
}

\begin{abstract}
*Corresponding Author: Olusola Ayo-Obiremi, Lecturer, The Nigerian Baptist Theological Seminary, Ogbomoso, Oyo State, Nigeria
\end{abstract}

\begin{abstract}
The African scholar comes from a background which is embodied in music, dance, mysticism, religion and various blends of cultural creativity and expression. The African scholar, first affected by colonialism, is exposed to European (Western) education which also brings Western civilization, western ways of thinking and western ideologies. Western ideas, dressing, culture and even scholasticism tend to be viewed as superior to African culture because the colonial masters made it look so and the African accepted this. For a long time, non-Africans wrote the African story (arguably to suit their own motives and not that of the African). There is tension due to the foregoing, and the African scholar tends to be alienated - neither fully African nor European, a stranger to his own heritage. Should colonialism continue through education and scholarship now that Africans are writing their own story? How does the insider-outsider debate in study of religions come into this tension? How can the problem of alienation be solved or reduced? This paper answers some of these questions and proposes a hybrid where African ideas, culture and background are elevated for global recognition and acceptance with European methods, styles and contributions as a springboard (because they have been documented, standardized, recognized and internationally accepted before African ideas were documented).
\end{abstract}

Keywords: African scholar, insider, outsider, alienation, empathetic interpolation, hybridity

In contributing to the debate ${ }^{1}$ as to whether the African scholar is an 'alienated self' in the academia or not, a few terms call for clarification. The 'African scholar' in this paper refers to one who as an academician has a citizenship in any African country by birth and not by naturalization ${ }^{2}$ and who is also from an African lineage. 'Alienated self' refers to one who is lost in the sense of not having a clear-cut identity; one who is a stranger; who has an identity crisis or confusion in terms of 'belonging.' I am approaching this response as a student of religions but also as an African (Nigerian) Christian minister with backgrounds in Christian Education and English Language. I was brought up from the ages four to nine in Louisville, Kentucky, United States of America; and so, have been involved in both American and Nigerian cultures. Some of these come to play in my analysis but I have sought to objectively portray authors before drawing conclusions. I look at some relevant history, the issues of insider-outsider and hybridity and how they help to tackle the challenge of the African writer's 'alienation' from both sides of the debate, and then draw conclusions.

The insider refers to one who belongs to a (sociological) group; she adheres, conforms to and accepts their beliefs, culture and practice; is a part of the deeper level experiences, understanding, preferences and prejudices of the given group. The outsider on the other hand does not have the benefit of details nor beyond-surface level beliefs of the group. While the insider is emotionally and sentimentally attached to the group's practices, the outsider has the benefit of a broader, more analytical perspective

\footnotetext{
${ }^{1}$ There are debates as to whether the African scholar is alienated or not as many ongoing debates on the matters of etic/emic and insider/outsider discussions.

Many writers have considered the impact of slavery and western civlization as well as the ripple effects of the contact of Africans with the Western world on Africans, leading to alienation. For instance, Lauren Breen writes on how individuals try to belong as 'insiders' and thus, are no more authentic.

Breen, Lauren J. 2007. 'The researcher 'in the middle': Negotiating the insider/outsider dichotomy.' The Australian Community Psychologist. 19 (1): pp. 163-174.

${ }^{2}$ There are Westerners (where 'Westerners' refer in this paper to all outsiders/non-Africans, especially those from the so called 'first world') who have stayed long enough in Africa to naturalize or who have actually naturalized.
} 
with the intent of organizing findings, systematizing observations and comparing various groups in order to be able to postulate theories guiding groups generally. The outsider misses the affective aspect of group life, being estranged from the group himself. ${ }^{3}$ Issues of belonging raise other matters such as hybridity and reflexivity which are key issues worth discussing. Some history is necessary to appreciate these terms.

The history of the study of religions in (sub-Saharan) Africa may be divided into two, ${ }^{4}$ partly overlapping phases: 'Africa as object,' when its religions were studied virtually exclusively by scholars, and other observers, from outside Africa; and 'Africa as subject' of the study of its religions when the religions of Africa had begun to be studied also, and increasingly mainly, by African scholars. ${ }^{5}$

The period when Africa was 'object' and her religions studied by outsiders mostly was during the colonial time. Lassiter cites Makgoba's identification of motives behind the interest of this larger world of non-Africans in these terms: political, used to maintain intellectual neo-colonialism, to propagate Western culture to disrupt unity so a united African community (which they fear) will not become a reality; "to ensure that Africans do not become masters of their own destiny." Confirming this intention of non-Africans, Nyamnjoh, in an interview stated that "Africa has been a victim of arbitrary boundaries that have excluded people of the same culture and divided others culturally - the divide and rule strategy. ... This consequence of European colonization has created tensions for the excluded and others." Falola confirms the tension and division thus: "While the colonial system brought some material benefits to a few European-educated intellectuals, by and large it alienated and frustrated most Nigerians, who believed that colonial rule eroded traditional cultures and institutions". 8

According to Lassiter, the African authors he surveyed ${ }^{9}$ argued that the interests of non-Africans succeeded because Africans individually yielded to the overpowering influence of foreigners through their "unquestioning acceptance and conformity." "As people accepted the colonialists' views, their own people also brought their perspectives and demands which called for attention. "Therefore, the larger world, like (the African's) family and communal milieu, present(ed) the African individual with an equally formidable set of circumstances and requirements he (was) conditioned not to challenge, (was) dependent on and from which he (could not) escape." as an (unavoidable) influence ... did not alter the people's steadfastly African culture, but they did assimilate many European idiosyncrasies. ..." ${ }^{12}$ This was the genesis of the 'alienation' for the

\footnotetext{
${ }^{3}$ The researcher here combines explanations gleaned from a number of sources including Jan Platovet, "From Object to Subject: A History of the Study of Religions in Africa" in The Study of Religions in Africa Past, Present and Prospects, Jan Platvoet, James Cox, and Jacob Olupona (eds). (Cambridge: Roots and Branches, 1996), p. 105; Ann Bonner and Gerda Tolhurst. 'Insider-outsider perspectives of participant observation' London Vol. 9, Iss. 4, (2002): 7-19.

${ }^{4}$ This is Platovet's division. In literature, the divisions are four -oral literature, pre-colonial literature, colonial/slave narratives, and post-colonial literature.

5 Jan Platovet, "From Object to Subject: A History of the Study of Religions in Africa" in The Study of Religions in Africa Past, Present and Prospects, Jan Platvoet, James Cox, and Jacob Olupona (eds). (Cambridge: Roots and Branches, 1996), p. 105.

${ }^{6}$ James E. Lassiter,“African Culture and Personality: Bad Social Science, Effective Social Activism, Or A Call to Reinvent Ethnology?,"African Studies Quarterly: The Online Journal for African Studies citing p. 205, Makogba http://web.africa.ufl.edu/asq/v3/v3i3a1.htm. Accessed July 15, 2011

${ }^{7}$ Kangsen Feka Wakai ,Interview“'Imagined Realities and the African Writer's Role”(An Interview of novelist, playwright and scholar, Francis B. Nyamnjoh) The Frontier Telegraph (a Bi-monthly news publication) http://www.thefrontiertelegraph.com/content/110107/writer.html Accessed July 15, 2011.

${ }^{8}$ Toyin FalolaChapter 6 "Nationalist movements and independence, 1929 - 1960" in The History of Nigeria, Printed2008. Online Publication: 2012, Cambridge University Press https://doi.org/10.1017/CBO97805118197 11.010, p. 136.

${ }^{9}$ The African scholars focused on in James E. Lassiter's article included: Senegalese, Ghanaians; Kenyans and South Africans with the selected works of the writers spanning a period of thirty-five years all from three of Africa's major sub-regions - West, East and South--where the largest number of contemporary African scholars have intellectually pursed the issues associated with pan-African cultural and psychological traits and adaptive processes.

${ }^{10}$ Lassiter"African Culture and Personality..."http://web.africa.ufl.edu/asq/v3/v3i3a1.htm ${ }^{11}$ Ibid.

${ }^{12}$ Newsflavor "Africa Through the Eyes of Its People Part 2" September 21, 2010, http://newsflavor.com/world /africa/africa-through-the-eyes-of-its-people-part-two-of-2/, published by Beardmaster, Assessed July 15, 2011.
} 
African as he willingly imbibed the culture of another. He was not exactly like his forefathers any more. Neither was he like the non-African whose ways he had imbibed; his cultural milieu had changed.

One of the issues of current discussion and debate wherefrom is the discussion of whether the African can even write as an insider as he seems to be lost. Can he do a good job? Will it be genuine? What language will he use to capture all that he should? Would he be a true insider or another outsider? Does he even know where he stands or does he have to take orders from his 'masters?' Can the European/non-African be completely ignored so 'pure uninfluenced Africanness' can be conspicuous in African writing? These are some of the questions that easily come to mind and an attempt is made to address few of them in this essay.

Before one can properly study a religion, there is the need to understand it to a large extent. Cox submits that "myths and rituals provide the primary sources for seeing into the meaning of a religion." ${ }^{\prime 13}$ In that wise, to understand a religion, one needs to understand its myths and rituals. These myths and symbols are communicated through language and practices. The person born into the tradition, religion and culture of a particular context would then be seen as an 'insider' while the person who is not from that context would be the 'outsider.' While the 'insider' is expected to know the 'ins' and 'outs' of his religion and culture, it is not always so, given the dynamics of age, gender, status or caste in a given society. For example, details of rituals in many African religions are kept secret and known to those of a certain elderly age range - possibly only the males. So, others from that jurisdiction who are supposed to be 'insiders' are actually 'insider-outsiders' while those who are 'in' on the secrets and details of ritual and worship are the true 'insiders.' Adogame aptly captures the struggle in the insider/outsider ${ }^{14}$ paradigm in these words:

The negotiation and navigation of boundaries is usually very delicate and controversial venture because it often has cultural, religious, political and other undertones. The Insider or Outsider positions are much more complicated than they may appear due to their attendant tendency towards exclusivity and inclusivity. Does the mere fact that one belongs to a religious tradition or group automatically make him/her an insider? In a sense our answer could be in the affirmative but a more critical appraisal of this at the methodological level makes it rather problematic to generalize. ${ }^{15}$

Observation of religious experiences is not the same as participation in them, in essence. An Indian proverb states that one cannot condemn another unless he has walked a mile in his moccasins. In like manner, Adogame, citing Harper states, 'You never really understand a person until you consider things from his point of view ... until you climb into his skin and walk around in it., ${ }^{16}$ Adogame's words are confirmed when one considers the numerous African traditions, religions and cultures and their respective myths and rituals. In Africa, "Traditional Religion is part of African culture. One cannot separate oneself from traditional religion" $" 17$ and each religion and culture has its own peculiar symbols, metaphors, and language; thus making it more difficult (though not outright impossible) for the outsider to really grasp what is on the 'inside.' For example, Susanne Sawyer Wegner (also known as Iwinfunmi Adunni Olosha) who embraced the worship of Osun of Osogbo to the point of becoming a priest ${ }^{18}$ proves it is possible for one to 'walk in the skin of the African' by not only observing but also participating.

\footnotetext{
${ }^{13}$ James L. Cox, Rational Ancestors: Scientific Rationality and African Indigenous Religions (Cardiff: Cardiff Academic Press, 1998), 2.

${ }^{14}$ Adogame identified four distinct but interrelated schemas which can be identified as: insider-insider; insideroutsider, outsider-insider and outsider-outsider

${ }^{15}$ Afe Adogame "To be or not to be? Politics of Belonging and African Christian Communities in Germany" Religion in the Context of African Migration Afe Adogame and Cordula Weisskoppel (eds). (Bayreuth Germany: Bayreuth African Studies Series. 2005), 96.

${ }^{16}$ Adogame 'To be or not to be?', 95

${ }^{17}$ Daniel Saawuan Shishima, Akpenpuun Dzurgba \&Godwin Iornenge Akper CTH 491: "African Traditional Religion and Culture" Department of Religion and Philosophy, Benue State University, Makurdi/ National Open University of Nigeria School of Arts and Social Sciences. http://nouedu.net/sites/default/files/2017-03/CTH\%20491_0.pdf http://nouedu.net/sites/default/files/2017-03/CTH\%20491_0.pdf. Accessed July 3, 2012.

${ }^{18}$ Ulli Beier, The Return of the Gods. The Sacred Art of Susanne Wenger. Cambridge University Press, 1975. Also, Susan Wegner's house in Osogbo has become a place of tourist attraction. (Reported by Boluwaji, Faith Abimbola 'Perceived Factors Affecting the Patronage of Domestic Tourism in Osun State (A Dissertation submitted in Partial Fulfillment of the Requirements for Award of Master of Science in Management (Hospitality and Tourism Management) of Redeemer's University, Ede, 2017).
} 
For the African, art was functional. Art was used to teach and to communicate values, not just as a means of entertainment or personal expression nor as the production of the 'guild of artists.' "Song, dance and music," according to Ngugi, "were an integral part of a community's wrestling with its environment, part and parcel of the needs and aspirations of the ordinary man." ${ }^{19}$ For the European, on the other hand, song is for the vocalist (musician), dance is learned in school or dance class and music is a matter of choice. While this contrast could lead to a kind of essentialism, the point is the African is born into these concepts, lives in them and breathes them while other cultures need to learn them. Likewise, non African cultures have their 'inbuilt' experiences and customs which Africans may have to learn to understand them.

As is the case with the inbuilt rhythm and dancing, all the scholars surveyed by Lassiter believe there are categories and processes of thought that are unique to Africa. Despite the differences in dialects, cultures, customs and practices, Quayson, commenting on Achebe reports that still, there are more similarities than differences. "His point is that, while there are obvious differences, the similarities are even more striking than the differences. As I have mentioned, the same could be said for the response by African writers to the colonial situation and, indeed, for the generally didactic function of their works." ${ }^{20}$ African scholars also believe that the African way of "organizing and cognitively engaging the world derives from a strongly restrictive indigenous socio-cultural milieu, and that this approach to social life and the broader world has been negatively affected by Western cultural influences."21

While the African background emphasizes social communal living, the European lifestyle strives on individualism. The confusion of whether to continue in community or to be individualistic is evident in Africa today; hence aiding the problem of alienation of the African scholar. According to Quayson, Achebe sees the problems of African alienation as based on a 'fundamental theme.'

Chinua Achebe writes of "a fundamental theme [that] must first be disposed of". . . Stressing that African societies were "not mindless", Achebe concentrates on the idea that these societies "frequently had a philosophy of great depth and value and beauty, that they had poetry and, above all, they had dignity." He considers that it is this dignity that many African people "all but lost" during the colonial period and, significantly, that it is this dignity that they must regain:

The worst thing that can happen to any people is the loss of their dignity and selfrespect. The writer's duty is to help them regain it by showing them in human terms what happened to them, what they lost. There is a saying in Ibo that a man who can't tell where the rain began to beat him cannot know where he dried his body. The writer can tell the people where the rain began to beat them ${ }^{22}$

The African scholar now wrestles with issues of self dignity. She is bombarded with guilt of abandoning the ways of the fathers/ancestors as reminded by the aged in society, negritude writers and other African writers. She struggles with issues of whether to buy imported things which are made to look more appealing and is told are more durable. The African scholar daily faces decisions of whether to dress like an African to work and be castigated as not cooperating with authority or not being smart, or to dress like a European and be commended as being 'smart' but struggle with the feel of a sword through her conscience once she is persuaded and bold enough to extol African virtues in an academic debate and someone calls attention to the attire - that he/she is not a true African by dressing fully like a European.

Even at 'traditional African' functions such as traditional wedding (now called engagement- an Western term), the African scholar is so mixed up in his thinking that he combines African and European items for the dowry. She dresses half-half - neither here nor there - African wear, European make up or African fabric, sewn European style, etc. In child upbringing, the scholar, in a bid to help

\footnotetext{
${ }^{19}$ Ato Quayson, Self-Writing and Existential Alienation in African Literature: Achebe's Arrow of God Research in African Literatures - Volume 42, Number 2, Summer 2011, pp. 30-45. Accessed July 2011

${ }^{20}$ Ato Quayson, Self-Writing and Existential Alienation in African Literature: Achebe's Arrow of God.

${ }^{21}$ Lassiter, "African Culture and Personality ..."

${ }^{22}$ Quayson citing Chinua Achebe, "The Novelist as Teacher," in African Writers on African Writing, ed. G.D. Killam (London: Heinemann Educational Books, 1973), p. 8. The article first appeared in New Statesman, January 29, 1965.
} 
his child 'belong' and be able to hold his own in the intellectual world teaches him/her impeccable English but at times the African mother tongue suffers neglect and the child grows up thinking English is a better language than her mother tongue.

Beyond the home, the child of the African scholar is also made more confused at school through what they are taught and tend to be all the more alienated. Quayson writes, ${ }^{23}$ "So European-centred were the educational systems that in history, Ngugi claims, Africans learnt about the rise of the AngloSaxons as if "they were the true ancestors of the human race." A similar process is portrayed at work right through Britain's African territories." 24

The confusion is not only in history. It starts from pre-primary school. Till date, when the African child learns rudiments of reading and writing, he learns to match items with Western words and objects he may never have set eyes on before. Until recent times, children in Nigeria just learned 'A' for 'Apple' but did not have the privilege of tasting an apple. The same goes for other letters and words like ' $\mathrm{Y}$ ' for 'Yatch' and ' $\mathrm{X}$ ' for 'Xylophone'. The sad story of alienation continues: Quayson states,

Kofi Awoonor, in his study of the cultures and literature of Africa entitled The Breast of the Earth, directs attention towards the alienation, confusion, and uncertainty that set in for the educated African. Awoonor sees the "fundamental erosion of the African's confidence in himself" as beginning "with the first Christian convert." The African, writes Awoonor, "was cast in the white man's image, a woeful caricature of this man, without focus or identity." ${ }^{25}$ It can be seen as significant that both men Ngugi and Awoonor - explicitly rejected the Christian names that would infer an acceptance of that caricature of identity. ${ }^{26}$

Hence, the African scholar is no more an African in the pre-colonial sense of it. That notwithstanding, the African scholar is still quite African in the new sense of the 'new Africa' wrought by the dynamism which is not peculiar to Africa but which is found in every society. There is still a great gap between the outsider and the insider based on "religion (and, or its practices), race, ethnicity, class and gender. These gap(s) - whether in time or social space can be overcome but this is not easy." 27 Where the outsider studies the language and culture, religion, traditions, etc. and acclimatizes, they become 'outsider-insiders.' Cox gives some steps that the outsider may take in phenomenological studies to attain this level. They include: 'performing epoche,' 'empathetic interpolation,' 'maintaining epoche' and then going ahead to observe, take notes to describe the situation and continue with the rest of the steps. ${ }^{28}$ Here, epoche means stepping outside of oneself; emptying self of personal biases and personal templates, temporary 'suspension of personal judgments.'

Empathetic interpolation is in terms of 'taking on another's skin;' 'walking in his shoes,' putting oneself in another's position. While these steps provide a possible way out, "The crux of the problem is whether, how to and to what extent a scholar can study, understand, or explain the beliefs, words or actions of another." 29 Adogame and others ask very pertinent questions: "To what degree, if any, are the motives and meanings of human behaviours and beliefs accessible to the researcher who may not necessarily share these beliefs and who does not necessarily share in these practices? ... Are all human observers cut off from ever being able to see through their own biases, contexts and presuppositions? "Must we and can we climb out of our own skin? Can we ever walk in the shoes of another?"30

Perhaps people may try to 'step out' of their skin and into the skin of another, but, like the Yoruba adage goes 'eefin niwa.' Character/personality is smoke. No matter how you try to conceal it, it will

\footnotetext{
${ }^{23}$ Ata Quayson

${ }^{24}$ Ata Quayson

${ }^{25}$ Quayson's footnote cites, Kofi Awoonor, The Breast of the Earth: A study of the cultures and literature of Africa (New York: Doubleday, 1971), p. 30.

${ }^{26}$ Quayson's footnote states, "Ngugi rejected James Ngugi in favour of Ngugi wa Thiong'o and Awoonor is known as Kofi Awoonor rather than George Awoonor-Williams."

${ }^{27}$ Adogame, p. 101

${ }^{28}$ These steps are explained by Cox, taught his students in Zimbabwe and practiced by him as described in Rational Ancestors, pp. 4 - 10

${ }^{29}$ Adogame, 95

${ }^{30}$ Adogame, 95
} 
find a way out. The real person will still come to play in what people do and think - if not in the short term; it will in the long run. Some Westerners did not bother to step out of themselves into the world of the African. They either just took the agnostic stance of describing what they saw with no value judgments or they made use of 'insiders' who provided the information they needed, giving them the insights into the religion or culture being studied. Despite Cox's experience and knowledge on how to become like an insider, though an outsider; he still used his Zimbabwean students ${ }^{31}$ to find out myths and rituals in their own languages. He first of all taught them the steps to phenomenological study before having them practice it. While this solves some problems, it raises others. The assistant may be seen as a betrayer or stooge of the outsider and certain things may be hidden from him or her by the elders or those who should give more insight to the informant. The assistant may even choose on his/her own to withhold information. Writing on migrants, asylum seekers and refuges as informants; Adogame stated that "There is often the tendency of the informant to be partially open, telling part of the truth or not the whole truth, or to revert to fabrication of stories." ${ }^{\prime 32}$

Therefore, many of the 'Westerners' who were outsiders and tried to describe, interpret and write about African religions, never really got to the core of it all. Some did not understand the core of the language nor the real intricacies. In other instances, there were no equivalents in English to translate the words and processes. Their worldview was totally different from that of Africans. Where they wanted a word or precise definition, the African had a description. (For example, while "the European had become used to articulating belief in specially developed language to be put down on paper, ... the African society articulated its beliefs and practices). ${ }^{133}$ While Europeans had written literature at the time they first got to Africa, Africans had orature (oral literature) and were presented as having no literature at all just because it was not yet written. ${ }^{34}$

One of the obvious differences between the Europeans and Africans was that Africans did not have the 'ready-made answers' the Europeans expected. The difference in world view made interests differ. What non-Africans saw as important may not have been the same with what the African considered of utmost importance in his beliefs. So, there was large room for misunderstanding. Whether done on purpose or as 'sincere mistakes,' Africans felt misrepresented by foreigners in religion, culture and other areas. This led to reactions against the Westerners who were also the symbols of colonialism. The struggle continued till independence and thereafter and many things were written to debunk what some Europeans had written or portrayed and African scholars were involved in writing as insiders. The writings of non-Africans were found to be inadequate or misrepresenting of Africans in many cases; fulfilling their own agenda and not that of the African community. Though not writing on the subject of Africa, George Orwell notes that "All writers are vain, selfish. . . ." ${ }^{35}$ Furthermore, "Wainaina has written extensively on the West's tendency to judge Africa and African cultural output through the prism of clichés, patronizing tones and broad generalizations". ${ }^{36}$

The insider is in the best position to write about his/her own religion and religious practices. As a result, "African religions are now no longer the object of study by outsiders only. They have also become the object of intensive and extensive studies, of various sorts and kinds by African scholars ...because religions are important phenomena in all the societies of modern Africa...." ${ }^{37}$ However, some feel that the writing of Africans is no more 'pure.' They have been 'polluted' by Europeans, European ways of life and ideas. They no longer think like original Africans. They were only stooges and puppets of white men serving the purpose of the same colonial masters in another garb. The

\footnotetext{
${ }^{31}$ Cox, Rational Ancestors 1, 2,35 - 82

32 Adogame, 109

${ }^{33}$ T. O. Ranger and I.N. Kimambo (eds) The Historical Study of African Religion with special reference to East and Central Africa (London: Heinemann, 1972), 47

${ }^{34}$ Quayson, Self-Writing and Existential Alienation in African Literature: Achebe's Arrow of God Research in African Literatures - Volume 42, Number 2, Summer 2011, pp. 30-45 Chapter 1 "African independence and before: Telling the people where the rain began to beat them." Accessed July 23, 2011.

${ }^{35}$ George Orwell "Why I Write" quoted by Maria Popova in "On Why I Write: George Orwell on an Author's 4 Main Motives” Jun 25, 2012 https://www.theatlantic.com/entertainment/archive/2012/06/why-i-write-georgeorwell-on-an-authors-4-main-motives/258955/

${ }^{36}$ Culturetrip, “How Not To Write About Africa: An Interview with Binyavanga Wainaina" https://theculturetrip. com/africa/kenya/articles/how-not-to-write-about-africa-binyavanga-wainaina/Accessed June 29, 2018

${ }^{37}$ Platovet, 129
} 
writers, however have sought to make it clear through their writing that they have minds of their own. For instance, writers of African literature like Ngugi wa Thiongo, Amos Tutuola, Wole Soyinka, Chinua Achebe, Leopold Sedar Senghor and Ayi Kwei Armah, have made their mark in world literature. In an Internet 'paper' where 'newsflavor' compares and contrasts how four African authors $^{38}$ used autobiography to illustrate the concepts of culture and community; the writers of newsflavor concluded that:

They (the four writers) specify community and culture, they use impressive ways to make their key points, but like all good books they are not exactly alike, they all have comparisons and contrasts. Because of them, we can see what Africa is: it is a wondrous continent constructed from mystifying paradoxes. Non-Africans may never know what it feels like to be African, but by immersing themselves in the literary works of its native authors, they can however briefly. It is hard to say exactly what effect Africa has upon this world. But it is clear that without that "patchwork quilt" it would never be the same. ${ }^{39}$

That speaks volumes for the African writers who have done their continent proud. If they had not written as Africans, non-Africans would not be able to get the picture from the insider's point of view. Even in the field of religion, scholars like John Pobee, John Mbiti, 'Deji Isaac Ayegboyin, and feminist theologian Mercy Amba Oduyoye, etc. are world-class names and scholars to be reckoned with.

Many of these African scholars had to use English Language (or French) in addition to or even in the place of indigenous languages so as to reach a wider audience. Some claim that African scholars use English (or French) because they are not vast enough in their native languages to express themselves and sometimes the concepts they write on are alien to the African life. ${ }^{40}$ They see the use of English as still a mark of colonialism. "... Though one can trace the widespread nature of English language to the colonial times, there are also some parts of the world where English is spoken and taught" and the people in these parts do not have anything to do with British or American colonialism. ${ }^{41}$ What would they say of non-ex-colonial countries who use English (or French) now? Besides, in every African nation, and location, there are different dialects. Without a language that can be read across the continent, the coverage would be small. English also makes the material readable to the outsider to learn more about Africa and African religions. English enables the reader of a different language and culture to decipher the writer's message clearly. ${ }^{42}$

Jusewalla and Dasenbrock report that 'English is now spoken and written in every continent of the world... It is an important language in at least one quarter of the world's one hundred sixty countries. ${ }^{43}$ Even though the afore-mentioned scholars write in English, they portray African life and values. "Song, dance and music", according to Ngugi, "were an integral part of a community's wrestling with its environment, part and parcel of the needs and aspirations of the ordinary man." 44 African scholars in religion often make use of the songs, poems, parables, proverbs, illustrations and literary devices from their African background. Oduyoye, for example, uses beads figuratively in her books. ${ }^{45}$ She also makes a lot of references to native proverbs, songs, ${ }^{46}$ etc. which she translates and explains in her writing. Even the cover of her book Daughters of Anowa shows an African setting and

\footnotetext{
${ }^{38}$ Newsflavor "Africa Through the Eyes of Its People Part 2" September 21, 2010, http://newsflavor.com/world/ africa/africa-through-the-eyes-of-its-people-part-two-of-2/. The four authors compared were Antjie Krog, J. Nozipo Maraire, Es'kia Mphahlele, and Wole Soyinka,

${ }^{39} \mathrm{http} / / /$ newsflavor.com/world/africa/africa-through-the-eyes-of-its-people-part-two-of-2/

${ }^{40}$ F-K Omoregie, "Rodney, Cabral and Ngugi as Guides to African Postcolonial Literature" English Department, University of Botswana. In Guides to African Post-Colonial Literature ( Internet article, posted February 24, 2005). http://www.africaspeaks.com/reasoning/index php? Accessed July 15, 2011

${ }^{41}$ Feroza Jussawalla and Reedway Dasenbrock, Interviews with Writers of the Post-Colonial World e-book, p. 1

${ }^{42}$ F-K Omoregie, "Rodney, Cabral and Ngugi as Guides ..."

${ }^{43}$ Jussawalla and Dasenbrock, 'Interviews with Writers...' e-book

44، African independence and before"http://wwwmcc.murdoch.edu.au/ReadingRoom/litserv/Webb/ch1.html Accessed July 16, 2011

${ }^{45}$ Mercy Amba Oduyoye, Beads and Strands: Reflections of an African Woman on Christianity in Africa (Maryknoll, New York: Orbis Books, 2004), 102and Mercy Amba Oduyoye, Daughters of Anowa: African Women and Patriarchy (Maryknoll, New York: Orbis Books 2000), vii, 209, etc.

${ }^{46}$ Oduyoye, Beads and Strands, 67, 102, 103, etc.
} 
African women. In addition, chapter headings and titles of books are African in 'thinking' as they project African imagery through word pictures. ${ }^{47}$

African scholars of African religions are now contributing their part to the worldwide academic study of the religions of humankind in a substantive manner. They have taken their place in the global community of the academic study of religions. ...African scholars of African religions need to be in constant touch with that worldwide community in matters of methodology. They need to continue to contribute to, and to participate in, the critical discussion of the matter, motives and methods of the academic study of religions. ${ }^{48}$

Now that Africans are writing, they need to learn from tested and proven methods in carrying out scholarly research. They have to build on the work of those who have written in English before them in different fields and sub-fields of scholarly writing. While the African playwright of English drama and the prose writer adheres to rules of grammar, syntax, figures of speech, appropriate use of idioms and so on, the writer in religions also has to obey rules of grammar enough to communicate but also needs to follow models in his/her area of specialization or chosen area of research and writing in religions - be it phenomenological, philosophical, theological, feminist, psychological, anthropological $^{49}$ or any other. The scholar would be so addressed and acknowledged only if (s)he keeps within expected and specified structures in her field. Unfortunately, however, as at the time of Lassiter's survey; "With the exception of Gyekye (1988), the African scholars surveyed failed to clearly and consistently link their assertions and arguments to historical and ethnographic data." African scholars in the study of religions must not fall short of expected methods in their scholarship. Originality is welcome but not anything below set standard methods and general expectations. Originality would be recognized by means of new discoveries in terms of combination, modes of expression, application, a "synthesis that has not been made before," ${ }^{, 51}$ using already known material but with new interpretation ${ }^{52 \text { "discovery of new facts, independent critical thought" }}$ "53 but not for making a mess of established processes and protocols in a given field. Hence, earlier writers, whether they are outsiders or insiders are needed to provide the guidelines and be the "horses in front that those behind follow their example. ${ }^{54}$ Moving forward, the African scholar can rupture the existing stereotype by not just meeting but beating the methods on ground. She should come up with methods and content that elevate Africa and Africans and thus, earn global recognition for her continent.

Cox cites Bediako that "The West, which lives in post-Christendom and 'World Christianity' era can learn from the study of African Christianity ... Africa can ... become the Christian laboratory for the world demonstrating that "Christian uniqueness" or distinctiveness need not be lost in the midst of pluralism. ${ }^{, 55}$ Falola's ideology of pluriversalism encourages such African uniqueness. "This requires that African sources, African insights, African-derived theories, African epistemologies, and African experiences become the major framework that motivates scholarship from the continent. But, ... critical to Falola's arguments, there is no escaping the imperatives of global scholarship." ${ }^{, 56}$ In addition, "It has been proved by a number of well-known anthropological monographs that any

\footnotetext{
${ }^{47}$ Examples are 'Covenant and Community,' 'The People next door,' 'Poverty and Motherhood,' and 'The Fire of the smoke,' in Beads and Strands which a non-African would likely have titled 'neighborhood agreements,' neighbors, impoverished mothers, the roots/causes respectively or similar short titles and even The Pieces of the puzzle for the title of the book.

48 Platovet, 129

${ }^{49}$ Rose Mary Amenga-Etego "Research Methods and multimedia powerpoint slides, M.A. Religions Sandwich Programme" (Lecture Notes, class notes, SREL 610: University of Ghana, Legon) July, 2011

${ }^{50}$ Lassiter, 'African Culture and Personality ...'

${ }^{51}$ David Silverman, Doing Qualitative Research: A Practical Handbook, London: Sage Publications Ltd., 2005), 69 (citing Phillips and Pugh, 1994), 19.

${ }^{52}$ Silverman, Doing Qualitative Research, 69 (citing Phillips and Pugh, 1994), 19.

${ }_{53}$ Silverman, Doing Qualitative Research, 70.

${ }^{54}$ In a race or convoy of horses, the one behind watches those ahead of it. This is from a Yoruba saying 'Esin iwaju ni teyin I wo sare.' So, those coming behind need to watch those ahead of them to make it in academia. They will learn what to do as well as what to avoid.

${ }^{55}$ Cox, 30.

${ }^{56}$ Tunji Olaopa Premium Times https://opinion.premiumtimesng.com/2017/07/23/reconstructing-the-globalacademy-falola-and-african-scholarship-by-tunji-olaopa/ Accessed June 29, 2018
} 
successful research process includes both views from inside as well as outside. ${ }^{.57}$ No matter how much the nostalgia is for the old African way of life, history can no longer be rewound. The African scholar must find a way of making the most of where he/she is like writers and religion academics earlier mentioned have done. Both outsiders and insiders need one another. The outsiders need insiders as informants, respondents and even as research assistants at times. The insiders also need outsiders to have a measuring standard for what they write, to have others study them and their religions and culture from another point of view and so avoid or at least, reduce parochial mindedness and myopic views.

Insiders and outsiders, emic and etic ${ }^{58}$, believers and observers; all need each other to sharpen their skills in scholarship because 'fosi we otun, fotun we osi lowo fi $n$ mo.' This Yoruba proverb literally means that you have to wash the left with the right and the right with the left for both hands to be properly cleaned. We all need each other to make a better world but the onus is on Africans (who are our major concern) to beware lest they become pseudo Westerners by taking note of and preserving those things that are deemed positive in the culture like community, a sense of togetherness, kinsmanship (as opposed to Western individuality), dignity and so on. Once positive things in culture are kept and upheld, the hybrids will not be a mismatch but rather a beautiful patchwork - like quilt or beautiful patterns of 'kente' or 'aso oke 59 traditionally woven cloth with beautiful strands and patterns, done painstakingly and with much commitment and discipline. When this is taken into cognizance, my conclusion is that though the African scholar is neither 'African' in the sense our forefathers were, nor totally like the Westerners, (s) he is a hybrid, a special class. The African scholar enjoys the best of two worlds and so, is not alienated (in the sense that the African identity is clear still) but is an emerging masterpiece of a new breed in this new dynamic generation with the advantage of opportunities and exposure that his forebears did not have.

\section{REFERENCES}

[1] Adogame, Afe "To be or not to be? Politics of Belonging and African Christian Communities in Germany" in Religion in the Context of African Migration, edited by Afe Adogame, and Cordula Weisskoppel (eds). (Bayreuth Germany: Bayreuth African Studies Series. 2005).

[2] 'African independence and before' http://wwwmcc.murdoch.edu.au/ReadingRoom/litserv/Webb/ch1.html Accessed July 16, 2011

[3] 'Africa through the Eyes of Its People 2' http://newsflavor.com/world/africa/africa-through-the-eyes-ofits-people-part-two-of-2/ Accessed July 15, 2011

[4] Amenga-Etega, Rose Mary, "Research Methods and multimedia powerpoint slides", M.A. Study of Religions Sandwich Programme (Lecture Notes, SREL 120: University of Ghana, Legon) July, 2011

[5] Beier, Ulli, The Return of the Gods. The Sacred Art of Susanne Wenger. Cambridge University Press, 1975.

[6] Boluwaji, Faith Abimbola 'Perceived Factors Affecting the Patronage of Domestic Tourism in Osun State (A Dissertation submitted in Partial Fulfillment of the Requirements for Award of Master of Science in Management (Hospitality and Tourism Management) of Redeemer's University, Ede) 2017.

[7] Cox, James L. Rational Ancestors: Scientific Rationality and African Indigenous Religions, (Cardiff: Cardiff Academic Press, 1998).

[8] Culturetrip, "How Not To Write About Africa: An Interview with Binyavanga Wainaina" https:// the culturetrip.com/africa/kenya/articles/how-not-to-write-about-africa-binyavanga-wainaina/Accessed June 29, 2018

[9] Falolu, Toyin, Toyin Falolu Chapter 6 "Nationalist movements and independence, 1929 - 1960" in The History of Nigeria, Printed 2008. Online Publication: 2012, Cambridge University Press https://doi.org/10. 1017/CBO9780511819711.010, 136.

\footnotetext{
${ }^{57}$ Weisskooppel, 113.

${ }^{58}$ Emic and Etic are terms coined by Kenneth L. Pike from the linguistic terms phonemic and phonetic. Emic is the viewpoint of one inside as system of behaviour while etic studies behaviour from outside the system. While the former describes, the latter takes the descriptions and organises, systematises and compares. Also emic would be for just one system or group while etic compares various groups with the intent of arriving at a theory for all related systems.

${ }^{59}$ This idea is partially taken from Mercy Amba Oduyoye's Beads and Strands: Reflections of an African Woman on Christianity in Africa (Maryknoll, New York: Orbis Books, 2004), 103. While Kente and Aso oke are long strips of handwoven cloth joined together, important to Ghananians and Nigerians for wear on special occasions respectively; a quilt patchwork is a Western important old time blanket-like covering made of cut out patches of different types of fabric formerly hand sown to make a beautiful whole.
} 
[10] Jussawalla, Feroza and Dasenbrock, Reedway Interviews with Writers of the Post-Colonial World e-book, Accessed July 15, 2011

[11] Lassiter, James E. "African Culture and Personality: Bad Social Science, Effective Social Activism, Or A Call To Reinvent Ethnology?” African Studies Quarterly http://web.africa.ufl.edu/asq/v3/v3i3a1.htm

[12] Oduyoye, Mercy Amba, Beads and Strands: Reflections of an African Woman on Christianity in Africa (Maryknoll, New York: Orbis Books, 2004)

[13] Oduyoye, Mercy Amba, "Culture and Religion as Factors in Promoting Justice for Women" in Women in Religion and Culture: Essays in Honour of Constance Buchananedited by Oduyoye, Mercy Amba (ed.) (Ibadan, Nigeria: Sefer Books Ltd., 2007).

[14] Oduyoye, Mercy Amba, Daughters of Anowa: African Women and Patriarchy (Maryknoll, New York: Orbis Books 2000)

[15] Olaopa, Tunji "Reconstructing the Global Academy: Falola and African African Scholarship". Premium Times https://opinion.premiumtimesng.com/2017/07/23/reconstructing-the-global-academy-falola-andafrican-scholarship-by-tunji-olaopa/ Accessed June 29, 2018

[16] Omoregie, F-K. "Rodney, Cabral and Ngugi as Guides to African Postcolonial Literature" English Department, University of Botswana. In Guides to African Post-Colonial Literature (Internet article, posted February 24, 2005). http://www.africaspeaks.com/reasoning/index php? Accessed July 15, 2011

[17] Orwell, George. "Why I Write" in "Why I write: George Orwell on an Author's 4 Main Motives" by Maria Popovahttps://www.theatlantic.com/entertainment/archive/2012/06/why-i-write-george-orwell-on-anauthors-4-main-motives/258955/Accessed June 29, 2018

[18] Platvoet, Jan 'From Object to Subject: A History of the Study of Religions in Africa' in Platvoet, Jan, Cox, James, and Olupona, Jacob (eds). The Study of Religions in Africa Past, Present and Prospects, (Cambridge: Roots and Branches), 1996

[19] Quayson, Ato Self-Writing and Existential Alienation in African Literature: Achebe's Arrow of God. Research in African Literatures - Volume 42, Number 2, Summer 2011, pp. 30-45, Accessed July 23, 2012

[20] Ranger, T. O. and Kimambo, I.N. (eds) The Historical Study of African Religion with special reference to East and Central Africa (London: Heinemann, 1972) p.47

[21] Saawuan, Daniel Shishima, Dzurgba, Akpenpuun \& Akper, Godwin Iornenge. CTH 491: 'African Traditional Religion and Culture' National Open University of Nigeria School of Arts and Social Sciences. http://nouedu.net/sites/default/files/2017-03/CTH\%20491_0.pdf Accessed on line July 3, 2012.

[22] Silverman, David Doing Qualitative Research: A Practical Handbook, (London: Sage Publications Ltd., 2005)

[23] Wakai,Kangsen Feka, "Imagined Realities and the African Writer's Role" (An Interview of novelist, playwright and scholar, Francis B. Nyamnjoh). The Frontier Telegraph (a Bi-monthly news publication) http://www.thefrontiertelegraph.com/content/110107/writer.html Accessed July 15, 2011.

[24] Weisskoppel, Cordula "In and Out: Doing Ethnographic Research in a German-Sudanese Sufi Brotherhood" in Religion in the Context of African Migration Adogame, Afe and Cordula Weisskoppel (eds). (Bayreuth Germany: Bayreuth African Studies Series. 2005).

\section{AUTHOR BIOGRAPHY}

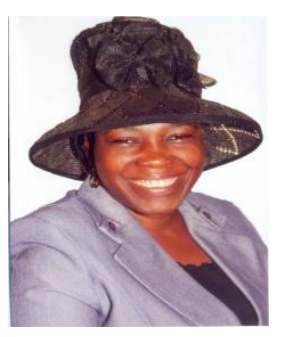

Olusola Ayo-Obiremi holds Masters' level degrees in Education, the Study of Religions and Youth Ministry. She holds a PhD in Christian Education. She is a Senior Lecturer in The Nigerian Baptist Theological Seminary, Ogbomoso, Oyo State Nigeria and currently serves as the Dean, Faculty of Education.

Citation: Olusola Ayo-Obiremi. "The African Scholar as an 'Alienated Self". International Journal of Humanities Social Sciences and Education (IJHSSE), vol. 6, no.10, 2019, pp. 117-126. doi: http://dx.doi.org/ 10.20431/2349-0381.0610014.

Copyright: (c) 2019 Authors. This is an open-access article distributed under the terms of the Creative Commons Attribution License, which permits unrestricted use, distribution, and reproduction in any medium, provided the original author and source are credited. 